Archive for

Organic Chemistry

Arkivoc 2020, part vii, 36-45

\title{
Modulation of the acidity of the 8-carboxamide group in the temozolomide family of antitumor imidazo[5,1-d][1,2,3,5] tetrazines $^{\dagger}$
}

\author{
Helen S. Summers, ${ }^{a}$ Magdalena B. Foreiter, ${ }^{a}$ William Lewis, ${ }^{a}$ Christopher J. Moody, ${ }^{a} *$ \\ Tracey D. Bradshaw, ${ }^{\mathrm{b}} *$ and Malcolm F. G. Stevens ${ }^{\mathrm{b} *}$ \\ ${ }^{a}$ School of Chemistry, and ${ }^{b}$ School of Pharmacy, University of Nottingham, NG7 2RD UK \\ Email: c.j.moody@nottingham.ac.uk; tracey.bradshaw@nottingham.ac.uk
}

Dedicated to Professor Jan Bergman on the occasion of his $80^{\text {th }}$ birthday

Received 02-19-2020

Accepted 04-28-2020

Published on line $05-06-2020$

\section{Abstract}

Imidazo[5,1- $d][1,2,3,5]$ tetrazines related in structure to the anticancer drugs temozolomide and mitozolomide with modification of the 8-carboxamide group, have been synthesized, $N$-nitrocarboxamides by direct nitration of the corresponding carboxamides, and $\mathrm{N}$-cyanomitozolomide by sodium cyanamide acylation. The $\mathrm{NH}$ groups in the $\mathrm{N}$-nitro- and $\mathrm{N}$-cyano-carboxamides were considerably more acidic than the parent carboxamide, and readily formed salts with morpholine and imidazole. X-Ray crystallography revealed that the $\mathrm{N}$-nitro compound existed as such rather than the nitronic acid tautomer. Preliminary evaluation showed that enhancing the acidity of the carboxamide $\mathrm{NH}$ in mitozolomide analogues was detrimental to the growth inhibitory activity.
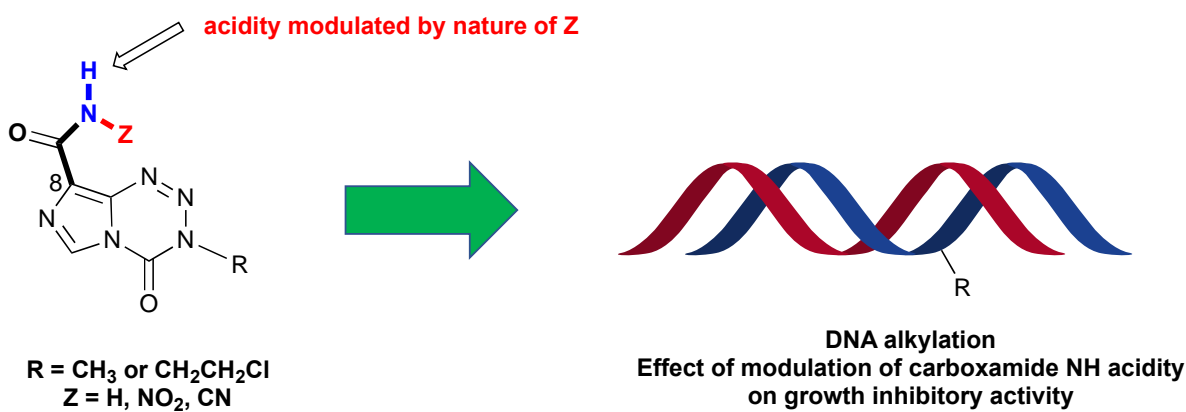

Keywords: Heterocyclic antitumor agents, imidazotetrazine, temozolomide, carboxamide acidity

${ }^{\dagger}$ Part 45 in the series 'Antitumor Imidazotetrazines'. Part 44 is ref. 1. 


\section{Introduction}

Remarkably, since the original synthesis in $1980^{2}$ of the anticancer drugs temozolomide (1, TMZ) and mitozolomide (2, MTZ) (Figure 1) and the subsequent marketing of $\mathbf{1}$ in 1999, no closely related small molecule agents have competed in the treatment of glioblastoma multiforme (GBM), the most prevalent and aggressive adult primary brain tumor. This class of anticancer imidazo[5,1- $d][1,2,3,5]$ tetrazines has been extensively reviewed from chemical, biological and clinical perspectives. ${ }^{3,4}$ The clinical success of 1 was due, in part, to its synthetic tractability (the original two-step Stone synthesis), ${ }^{2}$ or more recently via the trimethylsilylmethyl derivative 3 (Figure 1). ${ }^{5}$ The compound was also free from metabolic liabilities and possessed robust pharmaceutical properties allowing convenient oral delivery to out-patients, with a surprisingly tolerable safety profile for what might be considered as a classical DNA-interactive 'cytotoxic' agent.

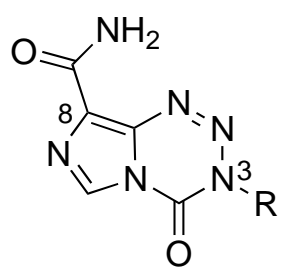

$1 \mathrm{R}=\mathrm{Me}$ (temozolomide: $\mathrm{TMZ}$ )

$2 \mathrm{R}=\mathrm{CH}_{2} \mathrm{CH}_{2} \mathrm{Cl}$ (mitozolomide: MTZ)

$3 \mathrm{R}=\mathrm{CH}_{2} \mathrm{SiMe}_{3}$<smiles>[Z]NC(=O)c1ncn2c(=O)n([R])nnc12</smiles><smiles>[R]c1ncn2c(=O)n(CCCl)nnc12</smiles>

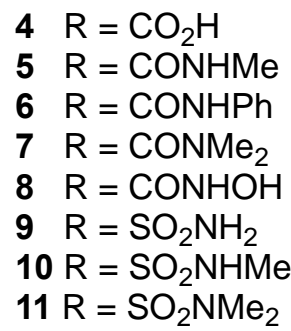

$12 \mathrm{R}=\mathrm{Me}, \mathrm{Z}=\mathrm{NO}_{2}$

$13 \mathrm{R}=\mathrm{CH}_{2} \mathrm{CH}_{2} \mathrm{Cl}, \mathrm{Z}=\mathrm{NO}_{2}$

$14 \mathrm{R}=\mathrm{CH}_{2} \mathrm{SiMe}_{3}, \mathrm{Z}=\mathrm{NO}_{2}$

$15 \mathrm{R}=\mathrm{CH}_{2} \mathrm{CH}_{2} \mathrm{Cl}, \mathrm{Z}=\mathrm{CN}$

Figure 1. Structures of anticancer imidazo[5,1-d][1,2,3,5]tetrazines.

In the early phase of work on imidazotetrazines, the synthesis of a range of derivatives of MTZ, modified at the 8-position was carried out, and their growth-inhibitory activities were evaluated against murine tumors in vitro and in vivo, including leukemias P388 and L1210 and the TLX5 lymphoma. ${ }^{6-9}$ Overall, it was concluded that a substituent at C-8 with a weakly acidic amide NH atom was apparently required for good inhibitory activity. Thus, although the parent carboxylic acid $4\left(p K_{a} \sim 3\right)$ was poorly active, high potency was recorded for MTZ 2 itself ( $\left.\mathrm{NH} \mathrm{p} K_{\mathrm{a}} \sim 15\right)$, a range of $\mathrm{N}$-alkyl- and -aryl carboxamides $\mathrm{NH}$ such as 5 and $6\left(\mathrm{NH} \mathrm{p} K_{\mathrm{a}} \sim 11-14\right)$, hydroxamic acid 8, sulfonamide $9\left(\mathrm{NH} K_{\mathrm{a}} \sim 9\right.$ ), and $\mathrm{N}$-methylsulfonamide 10 (Figure 1). The potently active dimethylcarboxamide 7, which does not present an acidic hydrogen, apparently contradicts this conclusion: however, in separate experiments, we showed that this tertiary amide is metabolized in mice in vivo (89\%) to the secondary monomethylcarboxamide $\mathbf{5}$ that does bear an acidic $\mathrm{H}$-atom. ${ }^{10}$ Presumably, the potency of the 8-dimethylsulfonamide $\mathbf{1 1}$ is also mediated via metabolism to the monomethylsulfonamide $\mathbf{1 0}$. This early work has been reviewed. ${ }^{11}$ We have now revisited the nature of the carboxamide substituent at $\mathrm{C}-8$, and focused on 
the modulation of $\mathrm{NH}$ acidity by incorporation of electron-withdrawing groups. We now report the synthesis and properties of the $N$-nitrocarboxamides $12-14\left(\mathrm{NH} \mathrm{p} K_{\mathrm{a}} \sim 3-4\right)$ and $N$-cyanocarboxamide $15\left(\mathrm{NH} \mathrm{p} K_{\mathrm{a}} \sim 6-7\right)$ (Figure 1).

\section{Results and Discussion}

Secondary $\mathrm{N}$-nitrocarboxamides $\left(\mathrm{RCONHNO}_{2}\right)$ are a relatively rare class of compounds with fewer than 100 examples reported (as at December 2019). They are generally prepared by direct nitration of carboxamides using $\mathrm{HNO}_{3} / \mathrm{H}_{2} \mathrm{SO}_{4},{ }^{7,12,13}$ or nitronium tetrafluoroborate, ${ }^{14,15}$ or less commonly by acylation of nitramines. ${ }^{16}$ In the imidazotetrazine series, we have reported previously that nitration of mitozolomide 2 in a nitric/sulfuric acid mixture gave the stable nitrocarboxamide 13 in $95 \%$ yield. ${ }^{7}$ We now find that the reaction can be extended to TMZ 1 and the TMS-methyl analogue 3 to give the nitrocarboxamides 12 and 14 respectively (Scheme 1), albeit in lower yield. Interestingly attempts to crystallize the latter compound from ethanol led only to the growth of crystals of the corresponding ethyl ester 16, presumably involving displacement of nitramine by the alcohol in a reaction analogous to trans-esterification reactions. Exploratory reactions treating 2 with nitronium tetrafluoroborate, nitronium acetate or nitronium trifluoroacetate in the presence of different bases gave complex mixtures from which the required nitrocarboxamide 13 could not be recovered. As expected on the basis of predicted $\mathrm{p} K_{\mathrm{a}}$ and literature precedent, ${ }^{13,17}$ the nitrocarboxamide $\mathbf{1 3}$ was sufficiently acidic to form salts readily with the bases morpholine (93\%), imidazole (82\%) as well as a sodium salt from sodium methoxide (75\%), and the structures of the morpholine and imidazole salts, together with 13 itself were confirmed by X-ray crystallography (Figures 2, S2-S4). Likewise, the structure of ethyl ester 16 was confirmed by crystallography (Figure S6). The X-ray crystal structures are discussed in more detail below.
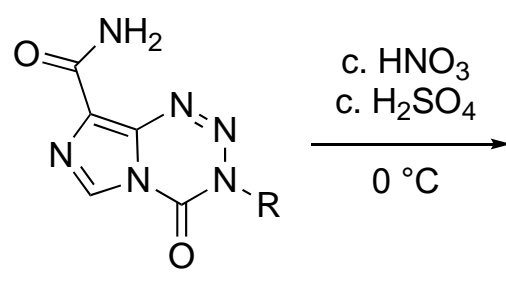

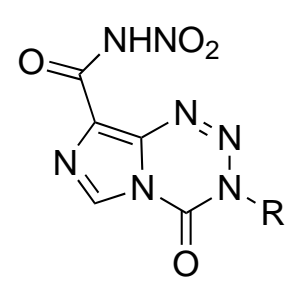

$12 \mathrm{R}=\mathrm{Me}(19 \%)$

$13 \mathrm{R}=\mathrm{CH}_{2} \mathrm{CH}_{2} \mathrm{Cl}(95 \%)^{a}$

$14 \mathrm{R}=\mathrm{CH}_{2} \mathrm{SiMe}_{3}(50 \%)$

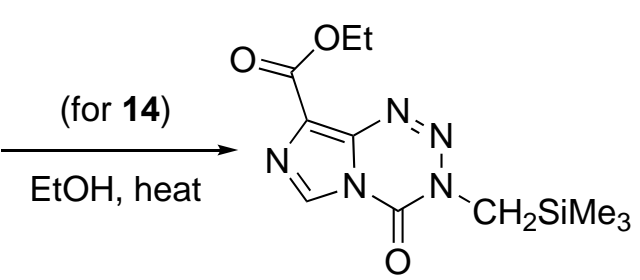

16

Scheme 1. Synthesis of $N$-nitrocarboxamides $12-14$ (Reference 7).

In contrast to $\mathrm{N}$-nitrocarboxamides, $\mathrm{N}$-cyanocarboxamides are relatively well known. They are usually prepared by acylation of cyanamide or its sodium salt, most often with an acid chloride, ${ }^{18}$ or by cyanation reactions with cyanogen bromide. ${ }^{18}$ Therefore our attention then turned to the synthesis of the $N$ cyanocarboxamide $\mathbf{1 5}$ by acylation of cyanamide. As previously reported, reaction of MTZ 2 with nitrosylsulfuric acid (from a mixture of sodium nitrite and sulfuric acid) proceeded via the intermediate $N$ nitrosoamide, which was not isolated, to afford the carboxylic acid 4 (77\%), ${ }^{13}$ the structure being confirmed by X-ray crystallography (Figure S1). The acid chloride $\mathbf{1 7}$ had been prepared previously from the corresponding acid $\mathbf{4}$ and thionyl chloride/DMF. ${ }^{7}$ In the present work, attempts to condense this unstable acid chloride with 
sodium cyanamide gave only mixtures and none of the required $\mathrm{N}$-cyanoamide 15 was recovered. More success was achieved by treating 4 with an oxalyl chloride/DMF mixture followed by sodium cyanamide which gave 15 in a useful 61\% yield, presumably via its acid chloride 17 (Scheme 2); the presence of an IR band at $2,200 \mathrm{~cm}^{-1}$ confirmed the cyano-carboxamide structure of $\mathbf{1 5}$, and this was corroborated by an X-ray crystal structure determination (Figures 3, S5).

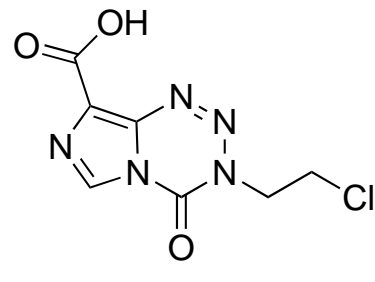

4

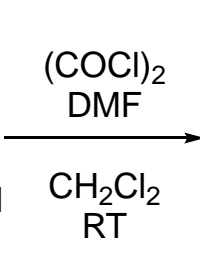

RT

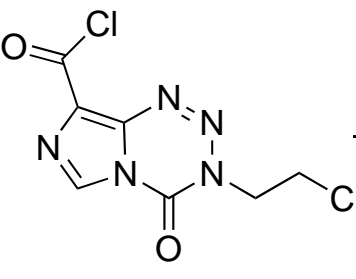

17

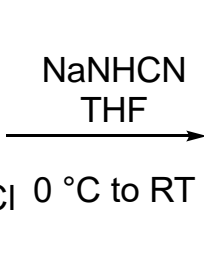

THF

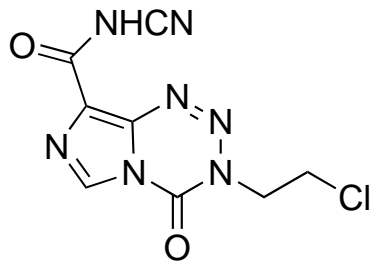

15

Scheme 2. Synthesis of the $N$-cyanocarboxamide 15.

$\mathrm{N}$-Nitro- and $\mathrm{N}$-cyano-carboxamides are under-explored classes of compounds and an X-ray structure of 13 was determined from a single crystal grown from $\mathrm{CHCl}_{3}$. The structure (Figure $2 \mathrm{~A}$ ) showed that the compound existed in the $\mathrm{N}$-nitro rather than the nitronic acid tautomeric form with an $\mathrm{N}-\mathrm{N}$ single bond length of $1.377 \AA$. Other $N$-nitrocarboxamides have very similar $N-N$ bond lengths in the solid state $(1.389 \AA$ and $1.380 \AA$ ).${ }^{19,20}$ In the unit cell of 13 there were intermolecular hydrogen bonds linking a nitrocarboxamide $\mathrm{N}-\mathrm{H}$ to $\mathrm{N}(1)$ of another tetrazine ring, and a nitrocarboxamide carbonyl oxygen atom to an $\mathrm{H}$ atom on $\mathrm{C}(8)$ of a second molecule (Figure $2 \mathrm{~B}$ ). The $\mathrm{N}$-nitro group was essentially coplanar with the imidazotetrazine nucleus (Figure 2C). A single crystal X-ray structure of the morpholinium salt of 13 (Figure 2D) confirmed that the $\mathrm{N}-\mathrm{N}$ bond order (1.376 $\AA$ ) was similar to 13 and existed in the $N$-nitro rather than the nitronic acid arrangement. The X-ray crystal structure of the imidazolium salt of $\mathbf{1 3}$ is shown in Figure S4 (SI).

\section{Biological investigations}

Preliminary biological investigation of the new compounds was carried out in three human cell lines: glioblastoma multiforme (GBM) U373V (vector control) and U373M (MGMT-transfected); colon HCT 116. The human GBM U373V line is relatively sensitive to TMZ and MTZ and gave $\mathrm{Gl}_{50}$ values of 51.9 and $11.3 \mu \mathrm{M}$, respectively. The isogenic line transfected with MGMT (U373M) showed approximately 6-fold and 3-fold resistance to $\mathrm{TMZ}(\mathbf{1})$ and MTZ (2) with $\mathrm{Gl}_{50}$ values of 302 and $33.9 \mu \mathrm{M}$, respectively. Conversion of the 8carboxamide groups of TMZ and MTZ into the corresponding $N$-nitrocarboxamides (12) and (13) and the $N$ cyanocarboxamide (15) substantially increases the acidity of the carboxamide $\mathrm{N}-\mathrm{H}$. In earlier studies nitrocarboxamide analogue of MTZ (13) proved to be as active as MTZ (2) against the murine TLX5 lymphoma growing in vivo, ${ }^{13}$ but this potency was not mirrored in activity against the human cancer cell lines in vitro when compared to that of the carboxamides (1) and (2), respectively, in the present study. The compounds $(12,13,15)$ all were approximately equiactive against U373V and M and colon HCT 116 cell lines. 
A.

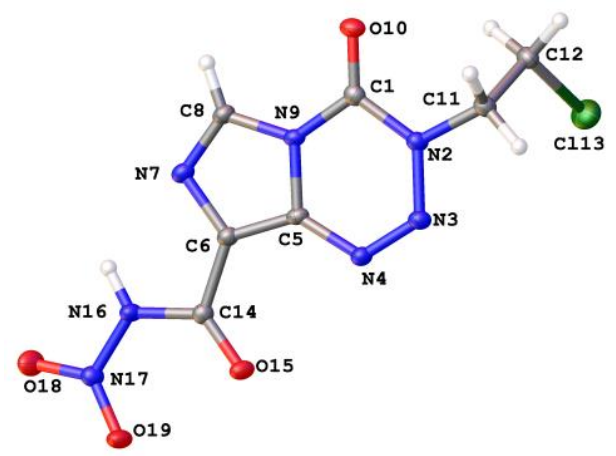

C.

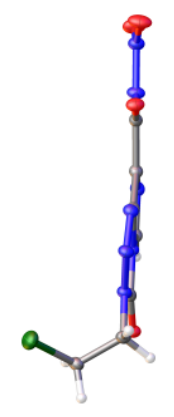

B.

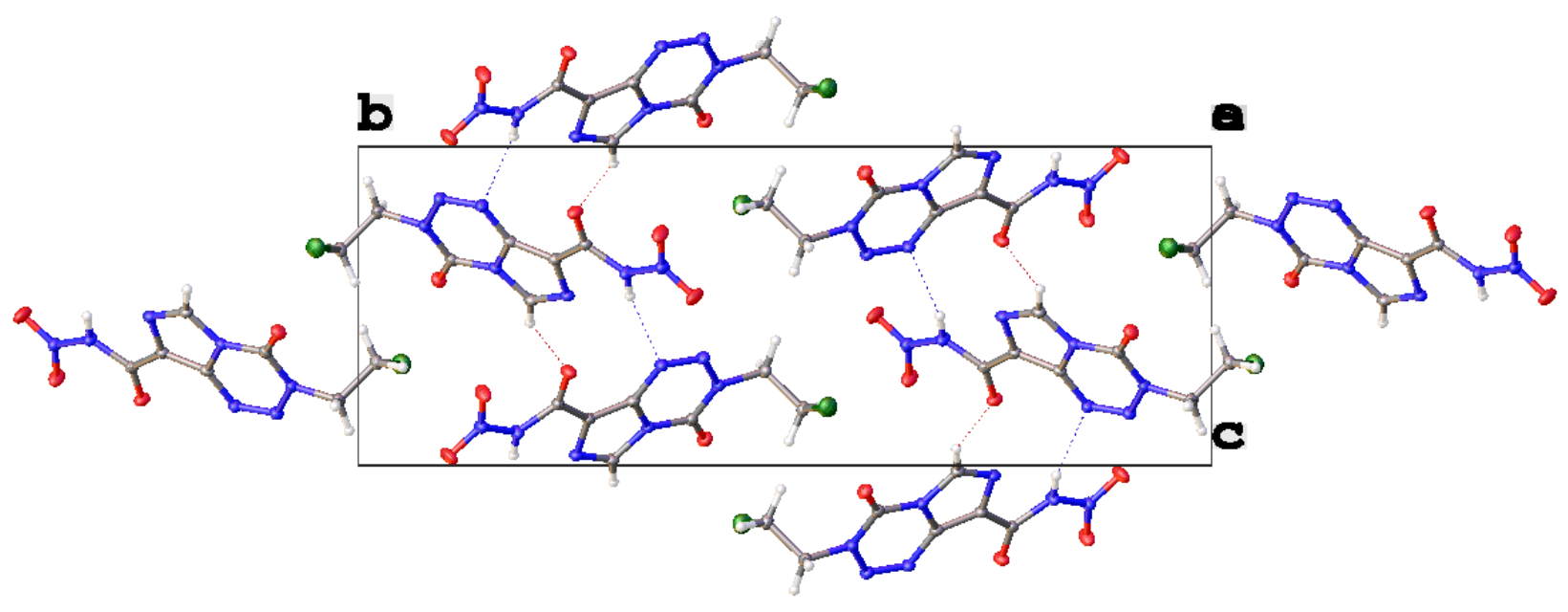

D.

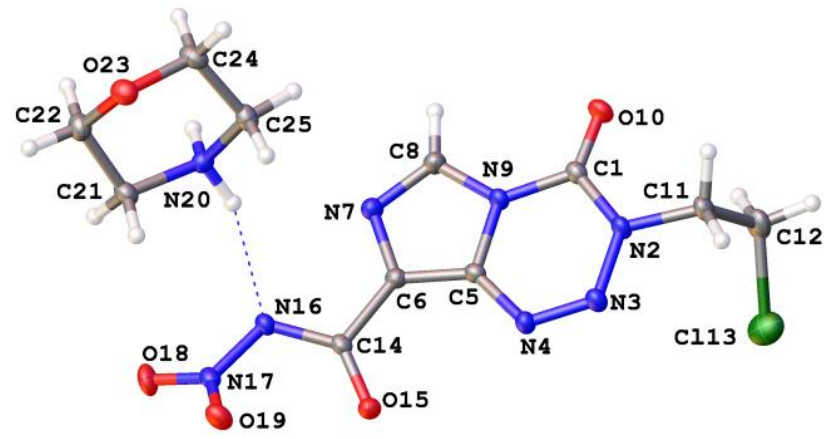

Figure 2. (A) X-Ray crystal structure of imidazotetrazine (13); (B) intermolecular H-bonding in the unit cell of (13); (C) coplanarity of nitrocarboxamide group and the bicyclic ring of (13); (D) structure of the morpholine salt of (13). 
A.

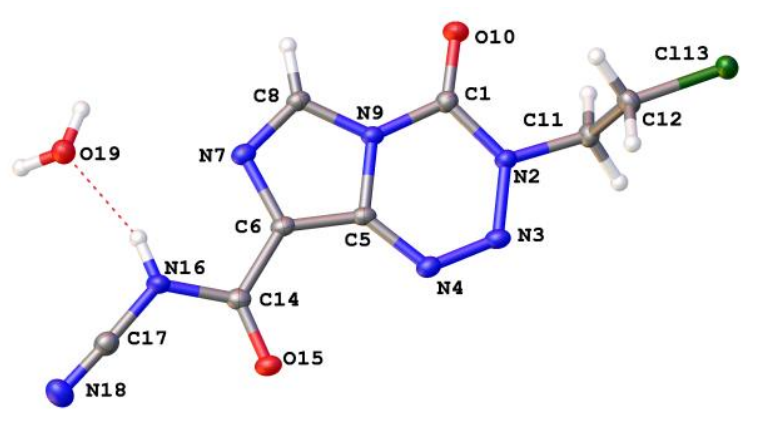

B.

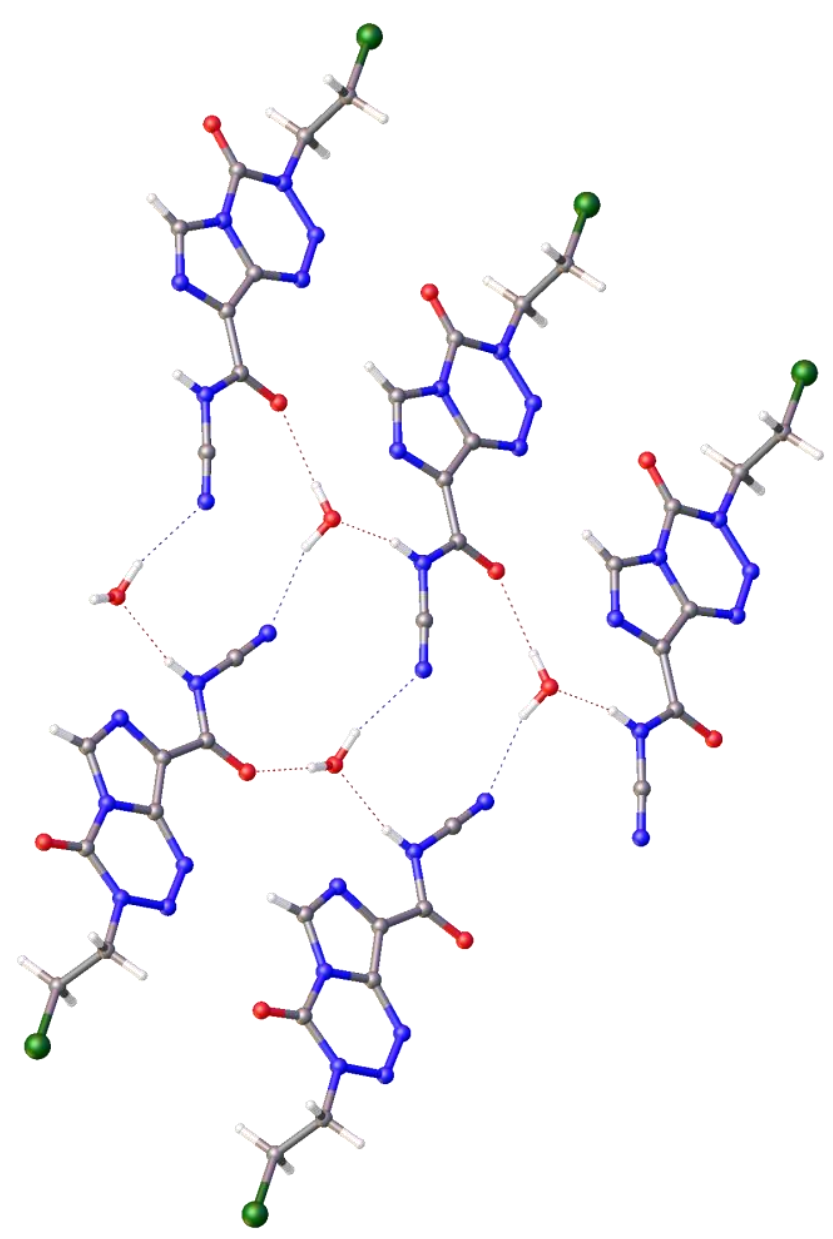

Figure 3. (A) Crystal structure of imidazotetrazine (15) hydrate; (B) intermolecular H-bonding between the cyanocarboxamide groups and water molecules.

\section{Conclusions}

Enhancing the acidity of the 8-carboxamide residue of MTZ (1) and TMZ (2) by conversion to N-nitro- (12 and 13) and an $\mathrm{N}$-cyano-derivative (15), respectively, has a profound dyschemotherapeutic effect, showing that strongly acidic groups are not tolerated. Although these new biological results do not contradict our previous contention that a weakly acidic group at C-8 in imidazotetrazines leads to potent anticancer activity in the series, they do not confirm that such a group is essential. Indeed, our most recent studies have focused on incorporation of a range of cyclic modifications of the 8-carboxamide group in an effort to control the stabilities of the imidazotetrazine ring structures, and allow fine-tuning of the pharmaceutical properties of future drug candidates. 


\section{Experimental Section}

General. Most imidazotetrazines decomposed in their melting ranges which varied according to the rate of heating. Melting points were not a reliable means to assess purity. Compounds were purified by crystallization or flash chromatography on Merck silica gel 60 .

The following compounds were prepared as previously described: TMZ (1) and MTZ (2), ${ }^{2}$ 8-carbamoyl-3(trimethylsilylmethyl)imidazo[5,1-d][1,2,3,5]tetrazin-4(3H)-one (3), ${ }^{5}$ 3-(2-chloroethyl)-3,4-dihydro-4-oximidazo[5,1-d] [1,2,3,5]tetrazine-8-carboxylic acid $(4),{ }^{7} \quad 3$-(2-chloroethyl)-8-( $N$-nitrocarbamoyl)imidazo[5,1- $\left.d\right]$ 1,2,3,5-tetrazin-4(3H)-one (13). ${ }^{7}$

3-Methyl-8-(N-nitrocarbamoyl)imidazo[5,1-d][1,2,3,5]tetrazin-4(3H)-one (12). An ice-cold suspension of TMZ (1) $(743 \mathrm{mg}, 3.8 \mathrm{mmol})$ in concentrated sulfuric acid $(8 \mathrm{~mL})$ was treated dropwise with nitric acid $(68 \% ; 4.5$ $\mathrm{mL}$ ). The reaction mixture was stirred at $0{ }^{\circ} \mathrm{C}$ for $2 \mathrm{~h}$ then poured onto ice. The precipitate formed was filtered under vacuum and washed with water to give 12 as a colorless crystalline solid $(172 \mathrm{mg}, 19 \%) ; \mathrm{mp} 180{ }^{\circ} \mathrm{C} ; \mathrm{v}_{\max }$ (ATR)/cm $\mathrm{cm}^{-1} 3251,3244,3131,1739,1703,1616,1562,1461,1421,1366,1295,1243,1209,1181,1124,1011$; $\delta_{\mathrm{H}}\left(400 \mathrm{MHz}, \mathrm{DMSO}-d_{6}\right) 8.91(1 \mathrm{H}, \mathrm{s}, \mathrm{CH}), 3.89\left(3 \mathrm{H}, \mathrm{s}, \mathrm{CH}_{3}\right) ; \delta_{\mathrm{C}}\left(100 \mathrm{MHz}, \mathrm{DMSO}-d_{6}\right) 161.8(\mathrm{C}), 139.0(\mathrm{C})$, 136.4.3 (C), $\left.129.0(\mathrm{CH}), 36.2\left(\mathrm{CH}_{3}\right) ; \mathrm{m} / \mathrm{z}(\mathrm{ESI}) 262[\mathrm{M}+\mathrm{Na}]^{+}, 29 \%\right) . \mathrm{MS}: \mathrm{m} / z$ Found: $[\mathrm{M}+\mathrm{Na}]^{+}, 262.0295$. $\mathrm{C}_{6} \mathrm{H}_{5} \mathrm{~N}_{7} \mathrm{O}_{4}^{+} \mathrm{Na}^{+}$requires 262.0284 .

8-(N-Nitrocarbamoyl)-3-(trimethylsilylmethyl)imidazo[5,1-d][1,2,3,5]tetrazin-4(3H)-one (14). An ice-cold suspension of the (trimethylsilylmethyl)imidazotetrazine (3) $(500 \mathrm{mg}, 1.88 \mathrm{mmol}$ ) in concentrated sulfuric acid $(4.7 \mathrm{~mL})$ was treated dropwise with nitric acid $(68 \% ; 1.9 \mathrm{~mL})$. The reaction mixture was stirred at $0{ }^{\circ} \mathrm{C}$ for $1 \mathrm{~h}$ then poured onto ice. The precipitate formed was collected and washed with cold water to give $\mathbf{1 4}$ as a solid (289 mg, 50\%); $\delta_{\mathrm{H}}\left(400 \mathrm{MHz}, \mathrm{DMSO}-d_{6}\right) 8.92(1 \mathrm{H}, \mathrm{s}, \mathrm{CH}), 3.84\left(2 \mathrm{H}, \mathrm{s}, \mathrm{CH}_{2}\right), 0.17\left(9 \mathrm{H}, \mathrm{s}, 3 \times \mathrm{CH}_{3}\right) ; \delta_{\mathrm{C}}(100 \mathrm{MHz}$, DMSO- $\left.d_{6}\right) 181.14,156.35,137.01,129.02,126.07,40.28,-1.93 . \mathrm{MS}: \mathrm{m} / \mathrm{z}$ Found: $[\mathrm{M}+\mathrm{H}]^{+}, 312.0871$. $\mathrm{C}_{9} \mathrm{H}_{13} \mathrm{~N}_{7} \mathrm{O}_{4} \mathrm{Si}^{+}+\mathrm{H}^{+}$requires 312.0871 .

Attempted crystallization from ethanol resulted in formation of crystals of ethyl 4-oxo-3-(trimethylsilylmethyl)imidazo[5,1-d][1,2,3,5]tetrazine-8-carboxylate (16).

3-(2-Chloroethyl)-8-(N-cyanocarbamoyl)imidazo[5,1-d][1,2,3,5]tetrazin-4(3H)-one (15). To a suspension of 3(2-chloroethyl)imidazo[5,1-d][1,2,3,5]tetrazin-4-oxo-8-carboxylic acid $(4)^{13}(0.5 \mathrm{~g}, 2.05 \mathrm{mmol})$ in dry DCM (3 $\mathrm{mL}$ ) under argon at room temperature was added oxalyl chloride $(0.58 \mathrm{~mL}, 10.3 \mathrm{mmol})$, followed by dry DMF (6 drops). The reaction mixture was stirred for $1 \mathrm{~h}$, concentrated under vacuum, dissolved in THF (5 mL) and added dropwise to a suspension of sodium cyanamide $(157 \mathrm{mg}, 2.46 \mathrm{mmol})$ in dry THF (10 mL) in an ice bath under argon. The reaction mixture was stirred for $18 \mathrm{~h}$ at room temperature, then the precipitated formed was collected. The filtrate was diluted with water $(20 \mathrm{~mL})$, extracted with EtOAc $(2 \times 25 \mathrm{~mL})$, acidified to $\mathrm{pH} 1$ with hydrochloric acid $(1 \mathrm{M})$ and the resulting precipitate was collected by vacuum filtration, washed with water and dried under vacuum to give 15 as a pink solid (total yield $337 \mathrm{mg}, 61 \%) ; v_{\max }\left(\right.$ ATR) $/ \mathrm{cm}^{-1} 2200$ (CN); $\delta_{\mathrm{H}}\left(400 \mathrm{MHz}, \mathrm{DMSO}-d_{6}\right) 9.06(1 \mathrm{H}, \mathrm{s}, \mathrm{CH}), 4.68\left(2 \mathrm{H}, \mathrm{t}, J 6.0, \mathrm{CH}_{2}\right), 4.04\left(2 \mathrm{H}, \mathrm{t}, J 6.0, \mathrm{CH}_{2}\right) ; \delta_{\mathrm{C}}(100 \mathrm{MHz}, \mathrm{DMSO}-$ $\left.d_{6}\right) 159.95,138.69,135.99,130.01,126.43,108.59,50.44,41.34$; LCMS: $R_{f} 1.918 \mathrm{~min}, \mathrm{MS}: \mathrm{m} / z[\mathrm{M}+\mathrm{H}] 268.0$, $[\mathrm{M}+\mathrm{Na}] 290.0$.

\section{Salt formation reactions}

(a) Imidazole $(0.9 \mathrm{eq}, 0.1 \mathrm{~g})$ was added to a suspension of $\mathrm{N}$-nitromitozolomide $13(1.738 \mathrm{mmol}, 0.5 \mathrm{~g})$ in acetonitrile $(7 \mathrm{~mL})$ and the mixture was stirred for $18 \mathrm{~h}$ at room temperature. As the reaction progressed, the 
particles in a suspension of starting material became finer. The solids were filtered off and washed with more acetonitrile and diethyl ether, then dried in vacuo, to give $(0.49 \mathrm{~g}, 82 \%)$ of 3-(2-chloroethyl)-8-( $N$ nitrocarbamoyl)imidazo[5,1-d][1,2,3,5]tetrazin-4(3H)-one imidazole salt hydrate, $\delta_{\mathrm{H}}\left(400 \mathrm{MHz}, \mathrm{DMSO}-d_{6}\right) 14.5$ $(1 \mathrm{H}, \mathrm{br}, \mathrm{NH}), 9.06(1 \mathrm{H}, \mathrm{s}, \mathrm{CH}), 8.73(1 \mathrm{H}, \mathrm{s}, \mathrm{CH}), 7.69(2 \mathrm{H}, \mathrm{s}), 2 \times \mathrm{CH}), 4.60\left(2 \mathrm{H}, \mathrm{t}, \mathrm{J} 6.0, \mathrm{CH}_{2}\right), 4.02(2 \mathrm{H}, \mathrm{t}, \mathrm{J} 6.0$, $\mathrm{CH}_{2}$ ).

(b) By analogy to the above procedure, using morpholine (1 equivalent), the initial suspension dissolved completely with the addition of a base, and within minutes the precipitate appeared. This gave (0.24 g, 93\%) of 3-(2-chloroethyl)-8-( $N$-nitrocarbamoyl)imidazo[5,1-d][1,2,3,5]tetrazin-4(3H)-one morpholine salt, $\delta_{H}(400$ $\left.\mathrm{MHz}, \mathrm{DMSO}-d_{6}\right) 8.83(1 \mathrm{H}, \mathrm{br}, \mathrm{NH}), 8.72(1 \mathrm{H}, \mathrm{s}, \mathrm{CH}), 4.60\left(2 \mathrm{H}, \mathrm{t}, J 6.0, \mathrm{CH}_{2}\right), 4.02\left(2 \mathrm{H}, \mathrm{t}, J 6.0, \mathrm{CH}_{2}\right), 3.76\left(4 \mathrm{H}_{\text {, }}\right.$ $\left.\mathrm{m}, 2 \times \mathrm{CH}_{2}\right), 3.12\left(4 \mathrm{H}, \mathrm{m} .2 \times \mathrm{CH}_{2}\right)$.

(c) Using $\mathrm{N}$-cyanomitozolomide 15 , the corresponding imidazole salt was prepared in $89 \%$ yield; $\delta_{\mathrm{H}}(400 \mathrm{MHz}$, DMSO- $\left.\left.d_{6}\right) 8.97(1 \mathrm{H}, \mathrm{s}, \mathrm{CH}), 8.70(1 \mathrm{H}, \mathrm{s}, \mathrm{CH}), 7.64(2 \mathrm{H}, \mathrm{s}), 2 \times \mathrm{CH}\right), 4.60\left(2 \mathrm{H}, \mathrm{t}, J 6.0, \mathrm{CH}_{2}\right), 4.02(2 \mathrm{H}, \mathrm{t}, J 6.0$, $\mathrm{CH}_{2}$ ), NH not observed.

(d) Using $\mathrm{N}$-cyanomitozolomide 15, the corresponding morpholine salt was prepared in $61 \%$ yield; $\delta_{\mathrm{H}}(400$ $\left.\mathrm{MHz}, \mathrm{DMSO}-d_{6}\right) 8.84(1 \mathrm{H}, \mathrm{br}, \mathrm{NH}), 8.66(1 \mathrm{H}, \mathrm{s}, \mathrm{CH}), 4.58\left(2 \mathrm{H}, \mathrm{t}, J 6.0, \mathrm{CH}_{2}\right), 4.01\left(2 \mathrm{H}, \mathrm{t}, J 6.0, \mathrm{CH}_{2}\right), 3.77(4 \mathrm{H}$, m, $\left.2 \times \mathrm{CH}_{2}\right), 3.13\left(4 \mathrm{H}, \mathrm{m} .2 \times \mathrm{CH}_{2}\right)$.

\section{Crystallography}

Details of X-ray crystallography are given in the Supplementary Material.

\section{Anti-proliferative assays}

Stock solutions of test compounds listed in were prepared in DMSO (100 mM) and aliquots stored at $-20^{\circ} \mathrm{C}$, protected from light. U373V and U373M were originally obtained from Schering-Plough Research Institute, USA and were verified as being mycoplasma free. Expression of MGMT in lysates prepared from U373M was verified by western blot. HCT 116 colorectal carcinoma cells were sourced from the American Type Culture Collection (ATCC). HCT 116 cells were maintained in RPMI 1640 nutrient medium supplemented with $10 \%$ fetal bovine serum (FBS), sub-cultivated twice weekly and incubated at $37{ }^{\circ} \mathrm{C}$ in an atmosphere containing $5 \% \mathrm{CO}_{2}$. For U373V and U373M cell lines, the medium was additionally supplemented with $1 \%$ non-essential amino acids, $50 \mathrm{\mu g} / \mathrm{mL}$ gentamicin and $400 \mu \mathrm{g} / \mathrm{mL}$ G418. 3-(4,5-Dimethylthiazol-2-yl)-2,5-diphenyltetrazolium bromide (MTT) assays were performed as reported previously. ${ }^{21,22}$ Compound concentrations required to inhibit $50 \%$ growth $\left(\mathrm{GI}_{50} ; \mu \mathrm{M}\right)$ were calculated using non-linear regression analysis.

\section{Supplementary Material}

Supplementary material (SI) available: crystallographic data. CCDC 1894718, 1894720, 1894722, 1895634, 1896795, 1896797.

\section{References}

1. Cousin, D.; Hummersone, M. G.; Bradshaw, T. D.; Zhang, J.; Moody, C. J.; Foreiter, M. B.; Summers, H. S.; Lewis, W.; Wheelhouse, R. T.; Stevens, M. F. G. Med. Chem. Commun. 2018, 9, 545-553. 
https://doi.org/10.1039/C7MD00554G

2. Stevens, M. F. G.; Hickman, J. A.; Stone, R.; Gibson, N. W.; Baig, G. U.; Lunt, E.; Newton, C. G. J. Med. Chem. 1984, 27, 196-201. https://doi.org/10.1021/im00368a016

3. Stevens, M. F. G. In Cancer Drug Design and Discovery; 2nd ed.; Neidle, S., Ed.; Elsevier Science: San Diego, 2014, p 145-164.

https://doi.org/10.1016/B978-0-12-396521-9.00005-X

4. Moody, C. L.; Wheelhouse, R. T. Pharamaceuticals 2014, 7, 797-838.

https://doi.org/10.3390/ph7070797

5. Wang, Y. F.; Stevens, M. F. G.; Thomson, W. T.; Shutts, B. P. J. Chem. Soc.-Perkin Trans. 1 1995, $2783-2787$. https://doi.org/10.1039/P19950002783

6. Lunt, E.; Newton, C. G.; Smith, C.; Stevens, G. P.; Stevens, M. F. G.; Straw, C. G.; Walsh, R. J. A.; Warren, P. J.; Fizames, C.; Lavelle, F.; Langdon, S. P.; Vickers, L. M. J. Med. Chem. 1987, 30, 357-366.

https://doi.org/10.1021/jm00385a018

7. Horspool, K. R.; Stevens, M. F. G.; Newton, C. G.; Lunt, E.; Walsh, R. J. A.; Pedgrift, B. L.; Baig, G. U.; Lavelle, F.; Fizames, C. J. Med. Chem. 1990, 33, 1393-1399.

https://doi.org/10.1021/jm00167a018

8. Clark, A. S.; Deans, B.; Stevens, M. F. G.; Tisdale, M. J.; Wheelhouse, R. T.; Denny, B. J.; Hartley, J. A. J. Med. Chem. 1995, 38, 1493-1504.

https://doi.org/10.1021/jm00009a010

9. Langnel, D. A. F.; Arrowsmith, J.; Stevens, M. F. G. Arkivoc 2000 (iii), 421-437.

10. Horspool, K. R.; Quarterman, C. P.; Slack, J. A.; Gescher, A.; Stevens, M. F. G.; Lunt, E. Cancer Res. 1989, 49, 5023-5026.

11. Stevens, M. F. G. In New Avenues in Developmental Cancer Chemotherapy; Academic Press: 1987, p 335353.

12. Campbell, R.; Peterson, C. J. J. Org. Chem. 1963, 28, 2294-2298.

https://doi.org/10.1021/jo01044a033

13. Axthammer, Q. J.; Krumm, B.; Klapotke, T. M. Eur. J. Org. Chem. 2015, 723-729.

https://doi.org/10.1002/ejoc.201403265

14. Olah, G. A.; Narang, S. C.; Olah, J. A.; Lammertsma, K. Proc. Natl. Acad. Sci. USA 1982, 79, 4487-4494. https://doi.org/10.1073/pnas.79.14.4487

15. Romea, P.; Aragones, M.; Garcia, J.; Vilarrasa, J. J. Org. Chem. 1991, 56, 7038-7042. https://doi.org/10.1021/jo00025a017

16. Bohle, D. S.; Chua, Z. J. Inorg. Chem. 2014, 53, 11160-11172.

https://doi.org/10.1021/ic5017033

17. Groziak, M. P.; Huan, Z. W.; Ding, H.; Meng, Z. Y.; Stevens, W. C.; Robinson, P. D. J. Med. Chem. 1997, 40, 3336-3345. https://doi.org/10.1021/jm970301s

18. Larraufie, M. H.; Courillon, C.; Ollivier, C.; Lacote, E.; Malacria, M.; Fensterbank, L. J. Am. Chem. Soc. 2010, 132, 4381-4387.

https://doi.org/10.1021/ja910653k

19. Liu, L.; He, C. L.; Li, Z. X.; Li, C. S.; Zhang, X. P.; Zhang, S. J. Acta Cryst. Sect. E-2011, 67, 0479-U1612. https://doi.org/10.1107/S1600536811002455 
20. Klenov, M. S.; Churakov, A. M.; Fedyanin, I. V.; Tartakovsky, V. A. Russ. Chem. Bull. 2016, 65, 2682-2685. https://doi.org/10.1007/s11172-016-1636-0

21. Zhang, J.; Stevens, M. F. G.; Bradshaw, T. D. Curr. Mol. Pharmacol. 2012, 5, 102-114. https://doi.org/10.2174/1874467211205010102

22. Zhang, J. H.; Hummersone, M.; Matthews, C. S.; Stevens, M. F. G.; Bradshaw, T. D. Oncology 2015, 88, 2848.

https://doi.org/10.1159/000366131

This paper is an open access article distributed under the terms of the Creative Commons Attribution (CC BY) license (http://creativecommons.org/licenses/by/4.0/) 